\title{
Sodium Sulphate Effect on Cement Produced with Building Stone Waste
}

\author{
Emre Sancak ${ }^{1}$ and Şükrüi Özkan ${ }^{2}$ \\ ${ }^{1}$ Department of Civil Engineering, Faculty of Technology, Suleyman Demirel University, West Campus, Cunur, 32260 Isparta, Turkey \\ ${ }^{2}$ Department of Construction, Technical Sciences Vocational High School, Suleyman Demirel University, 32260 Isparta, Turkey \\ Correspondence should be addressed to Emre Sancak; emresancak@sdu.edu.tr
}

Received 19 January 2015; Accepted 23 April 2015

Academic Editor: Kwansoo Chung

Copyright @ 2015 E. Sancak and Ş. Özkan. This is an open access article distributed under the Creative Commons Attribution License, which permits unrestricted use, distribution, and reproduction in any medium, provided the original work is properly cited.

In this study, the blended cements produced by using the building stone waste were exposed to sulphate solution and the cement properties were examined. Prepared mortar specimens were cured under water for 28 days and then they were exposed to three different proportions of sodium sulphate solution for 125 days. Performances of cements were determined by means of compressive strength and tensile strength tests. The broken parts of some mortar bars were examined with scanning electron microscope (SEM). Besides, they were left under moist atmosphere and their length change was measured and continuously monitored for period of 125 days. In blended cements, solely cements obtained by replacing $10-20 \%$ of diatomites gave similar strength values with ordinary Portland cement (CEM I 42.5R) at the ages of 7, 28, and 56 days. In all mortar specimens that included either waste andesite (AP) or marble powder (MP) showed best performance against very severe effective sodium sulphate solutions (13500 mg/L).

\section{Introduction}

The main idea of using different wastes such as by-product or natural was not only the cost effectiveness but also the improvement of the properties of concrete, especially durability, and protection of the habitat. The evaluability of building stone cutting and other processes wastes as a pozzolanic and nonpozzolanic material in construction sector has taken attention in last decades. Another approach to the utilisation of wastes and industrial by-products is to reduce fossil energy consumption on Portland cement (PC) production and aggregate consumption with regard to the environmental concern.

Sulphate attack is one of the most important matters concerning the durability of concrete structures. Under the sulphate environment, cement paste undergoes deterioration resulting from expansion, spalling, and softening [1-3]. Sulphate attack occurs in concrete when concrete is in contact with a source of sulphate ions, which can be groundwater, soil, or rainwater. Sulphate attack usually manifests itself by cracking and spalling of concrete accompanied by expansion and/or loss of strength. The resistance of concrete to sulphate attack is determined by several factors, such as water/cement, permeability, and cement properties, which include fineness and cement composition [4].

Some soils having the sulphate concentrations are moderate and severe, according to ACI 201 [5] as shown in Table 1. They indicate sulphate concentrations in soils from $0.11 \%$ to $0.70 \%$ and in groundwaters and wastewaters from 288 to $10000 \mathrm{ppm}[6]$.

The availability of lime in cement compounds causes the forming of secondary gypsum, and then this can also be placed in secondary ettringite formation. High lime rate in cement raises volume of microcrystalline ettringite that is responsible for exessive water adsorption and volumetric stability because of sulphate attack. Besides, lime restricts the solubility of aluminates that brings an expansive topochemical reaction $[4,7,8]$.

It is generally known that addition of pozzolan reduces the calcium hydroxide in cement paste and improves the permeability of concrete. This helps to increase the resistance of concrete to the sulphate attack and other harmful solutions 
TABLE 1: Severity of sulphate content [5].

\begin{tabular}{lcc}
\hline Severity of attack & $\begin{array}{c}\text { Soluble sulphate } \\
\text { in soil, wt. } \\
\text { percent }\end{array}$ & $\begin{array}{c}\text { Concentration } \\
\text { in water, ppm }\end{array}$ \\
\hline Mild & $0.00-0.10$ & 0 to 150 \\
Moderate & $0.10-0.20$ & 150 to 1500 \\
Severe & $0.20-2.00$ & 1500 to 10000 \\
Very severe & $2.00-$ more & 10000 or more \\
\hline
\end{tabular}

$[6,9]$. Besides, the increase in the service life of the structure made from the blended cement containing pozzolan would further reduce the amount of Portland cement use [1]. On the other hand, if the media has acidic character, the mortars made from Portland cement were better than the pozzolanic cement incorporated samples after 120 days of acid attack [10].

In the studies made on sulphate resistance of Portland cements containing natural puzzolans, in case of limestone additions on resistance to sulphate degradation are physicalthat is, addition of a few percent in Portland cement reduces the porosity and increases the resistance of Portland cement systems to sulphate; but higher addition of $25 \%$ increases porosity and lowers resistance to sulphate [11].

Resistance to sodium sulphate solution of $5 \%$ of blended cements has been shown to be relatively unaffected by pozzolans (fly ash-class $\mathrm{F}$ and ground rice husk ash) up to $40 \%[1]$.

Chen et al. studied the mechanical properties of cement mortars subjected to wet-dry cyclic sulphate attack. Their experimental results showed that the ultimate compressive strength increased with number of cycles at the initial stage. However, after a certain time, it started to decrease with further increases in the number of cycles. Moreover, researchers reported that the concentration of the sodium sulphate solution proved to be an important factor affecting the ultimate compressive strength [12].

In a study conducted by Aruntaş et al. (2010), waste marble dust (WMD) added cements conform to TS EN 197-1 standard and they reported also that 10\% WMD can be used as an additive material in cement manufacturing [13]. The compressive strength test results of cement mortar with marble powder wastes $(10 \%-20 \%$ by weight of cement) without superplasticizer have spreading value of $110 \pm 5 \%$; the increase was a range of $28-20 \%$ at 28 days [14]. The replacement of cement with diatomite and WMP ( $5-10 \%$ by weight of cement) separately and together using a superplasticizing admixture could be utilized to improve the mechanical properties of the conventional concrete mixtures [15].

In this study, the cements produced by the additive materials (pumice: PP, diatomite: DP, fly ash: FA, andesite powder: AP, and marble powder: MP) from Isparta, Turkey, and its surroundings which give pozzolanic activity are compared with CEM I 42.5 cement. In this comparison sulphate resistance and other cement properties are examined. The natural additives which undergone various procedures are blended with clinker and gypsum under different proportions, which are main cement compounds [16].

\section{Experimental Programme}

2.1. Materials. In the experimental studies, the clinker and gypsum obtained from Isparta Goltas Cement Factory were used.

Tables 2-3 summarize the properties of Portland cement clinker and the supplementary cementing materials utilized to prepare the specimens.

Besides, clinker has free $\mathrm{CaO}$ content of $1.005 \%$, MP has $\mathrm{CaCO}_{3}$ content of $94.66 \%$ (should be $>75$ according to the EN 197-1), and AP has FeO content of $1.08 \%$ and $\mathrm{MnO}$ content of $0.10 \%$. As shown in Table 2, while the material which contained the highest $\mathrm{SiO}_{2}$ is $\mathrm{DP}, \mathrm{MP}$ has the lowest $\mathrm{SiO}_{2}$.

The pozzolanic reaction comprised the amorphous silica within DP and the calcium hydroxide occured with hydration reactions of cement compounds and water that the microstructure of concrete turned to become more homogeneous and dense. This type (amorphous silica) of $\mathrm{SiO}_{2}$ reacted with $\mathrm{Ca}(\mathrm{OH})_{2}$ and produced calcium silicate hydrates (CSH), which were responsible for the development of strength $[15,17]$.

Because MP has the highest $\mathrm{CaO}$ content, cause of expansion and strength loss for cement mortar differ from other by-products [4].

On the other hand, in a study conducted by Agarwal and Gulati (2006), if the superplasticizer is used in mix, the compressive strength of mortar which included marble dust is comparable to control mortar. They also conducted a study with ternary cement mixes obtaied by blending fly ash $(20 \%)$, silica fume (10\%) and marble dust (10\%), and silica fume (10\%) [14].

Waste MP and AP retained after cutting of the gladding stone and PP supplied from Isparta region of Turkey were used as the additive materials in cement production. The diatomite ore from a deposit located in Keciborlu region of Isparta in Turkey was used. It is characterized as natural pozzolan material at TS EN196-1 [18].

The water used in mortar production was regular tap water. The sand used in the composition of the mortars mixtures was standard CEN type Normsand conforming to TS EN 196-3 [19].

The mixture proportions of constituents used for production of blended cement with additive are given in Table 4 .

Amount of FA and PP were fixed as 10\% by weight of cement in the all-blended cement specimens. Besides, the amount of gypsum was also fixed as $4 \%$ by weight of all cement compositions in this study. As shown in Table 4, the ground diatomite, andasite powder, and MP were used as partial replacement of PC clinker in the amount of $10 \%, 20 \%$, and $30 \%$ based on weight in total cement mass in order to obtain the composed cement with additive.

To obtain mean specific surface for blended cement types similar with reference cement, grinding period was held constant as 75 minutes. The same grinding period is applied for all supplementary materials.

To produce the blended cements, the oven dried diatomite and pumice were reduced by an impact crusher (firstly in small jaw crusher and secondly in big jaw crusher) to arrange for the grinding process and then separately 
TABLE 2: The chemical composition of the clinker and the supplementary cementing materials.

\begin{tabular}{|c|c|c|c|c|c|c|c|}
\hline \multirow{2}{*}{ Chemical composition } & \multicolumn{7}{|c|}{ Amount (\%) } \\
\hline & Clinker & Pumice & Fly ash & Diatomite & Andesite & Marble & Limits \\
\hline $\mathrm{SiO}_{2}$ & 21.01 & 60.50 & 53.23 & 85.50 & 57.1 & 0.67 & \\
\hline $\mathrm{Al}_{2} \mathrm{O}_{3}$ & 4.64 & 17.15 & 19.34 & 4.37 & 15.9 & 0.34 & \\
\hline $\mathrm{Fe}_{2} \mathrm{O}_{3}$ & 4.24 & 3.38 & 10.21 & 1.33 & 5.00 & 0.19 & \\
\hline $\mathrm{CaO}$ & 65.96 & 4.68 & 4.42 & 1.51 & 4.90 & 53.01 & \\
\hline $\mathrm{MgO}$ & 2.44 & 2.09 & 0.88 & 0.29 & 3.20 & 1.16 & $<5$ \\
\hline $\mathrm{K}_{2} \mathrm{O}$ & 0.91 & 4.54 & 2.85 & 0.75 & 6.40 & - & \\
\hline $\mathrm{SO}_{3}$ & 1.93 & 0.16 & 0.13 & 0.20 & - & - & $<5$ \\
\hline $\mathrm{Na}_{2} \mathrm{O}$ & - & 4.30 & 0.55 & 0.70 & 4.50 & - & \\
\hline $\mathrm{P}_{2} \mathrm{O}_{5}$ & 0.08 & - & - & - & 0.18 & - & \\
\hline $\mathrm{Cl}$ & 0.033 & - & 0.005 & - & - & - & $<0.1$ \\
\hline $\mathrm{S}+\mathrm{A}+\mathrm{F}$ & 29.89 & 81.03 & 82.78 & 91.20 & 78.0 & 1.2 & $>70$ \\
\hline Loss on ignition & & 2.64 & 8.30 & 2.74 & 0.15 & - & $<5$ \\
\hline
\end{tabular}

TABLE 3: Physical properties of materials used in this study.

\begin{tabular}{|c|c|c|c|c|c|c|}
\hline \multirow{2}{*}{ Property } & \multicolumn{6}{|c|}{ Material } \\
\hline & Clinker & Pumice & Fly ash & Diatomite & Andesite & Marble \\
\hline $\begin{array}{l}\text { Material retained on } \\
200 \mu \mathrm{m}(\%)\end{array}$ & 0.3 & 19.3 & 0.40 & 17.90 & 0.70 & 1.70 \\
\hline $\begin{array}{l}\text { Material retained on } 80 \mu \mathrm{m} \\
(\%)\end{array}$ & 1.84 & 73.85 & 14.72 & 43.01 & 22.54 & 21.75 \\
\hline Specific gravity $\left(\mathrm{g} / \mathrm{cm}^{3}\right)$ & 3.16 & $2.34-2.45$ & 2.05 & 2.35 & 2.39 & 2.73 \\
\hline $\begin{array}{l}\text { Specific surface (Blaine, } \\
\mathrm{cm}^{2} / \mathrm{g} \text { ) }\end{array}$ & 3294 & - & 4290 & - & - & - \\
\hline Loose unit weight $\left(\mathrm{g} / \mathrm{cm}^{3}\right)$ & - & 0.35 & - & 0.67 & 2,58 & 2.8 \\
\hline Colour & Dark gray & Off-whites yellowish & Dark brown & White & Dark gray & Cream \\
\hline Hardness (Mohs) & - & $5-5.5$ & - & - & - & 3 \\
\hline Organic substances & None & None & None & None & None & None \\
\hline $\begin{array}{l}\text { Water absorption (for } \\
5-10 \mathrm{~min} \text {. and for grain size } \\
\text { of } 2-7.5 \mathrm{~cm} \text { ) }\end{array}$ & 36.65 & - & - & 91.80 & 2.99 & 10 \\
\hline Apparent porosity (\%) & - & - & - & 61.50 & 14.27 & 0.2 \\
\hline $\begin{array}{l}\text { Compressive strength } \\
\left(\mathrm{kg} / \mathrm{cm}^{2}\right)\end{array}$ & & $29-47$ & & 60 & 887 & 704 \\
\hline
\end{tabular}

TABLE 4: Mixture proportions used on production of blended cement types.

\begin{tabular}{|c|c|c|c|c|c|c|c|c|c|c|}
\hline \multirow{2}{*}{ Constituents (\%) } & \multicolumn{10}{|c|}{ Cements codes } \\
\hline & $\mathrm{RC}$ & $\mathrm{DC1}$ & DC2 & DC3 & $\mathrm{AC} 1$ & $\mathrm{AC} 2$ & $\mathrm{AC} 3$ & $\mathrm{MC1}$ & MC2 & MC3 \\
\hline PC clinker & 96 & 66 & 56 & 46 & 66 & 56 & 46 & 66 & 56 & 46 \\
\hline Gypsum & 4 & 4 & 4 & 4 & 4 & 4 & 4 & 4 & 4 & 4 \\
\hline Diatomite & 0 & 10 & 20 & 30 & - & - & - & - & - & - \\
\hline Pumice & - & 10 & 10 & 10 & 10 & 10 & 10 & 10 & 10 & 10 \\
\hline Andesite & - & - & - & - & 10 & 20 & 30 & - & - & - \\
\hline Marble & - & - & - & - & - & - & - & 10 & 20 & 30 \\
\hline Fly ash & 一 & 10 & 10 & 10 & 10 & 10 & 10 & 10 & 10 & 10 \\
\hline Total & 100 & 100 & 100 & 100 & 100 & 100 & 100 & 100 & 100 & 100 \\
\hline
\end{tabular}


TABle 5: Physical properties of cement types.

\begin{tabular}{|c|c|c|c|c|c|c|c|c|c|c|}
\hline \multirow{2}{*}{ Characteristics } & \multicolumn{10}{|c|}{ Cements codes } \\
\hline & $\mathrm{RC}$ & $\mathrm{DC} 1$ & DC2 & DC3 & $\mathrm{ACl}$ & AC2 & AC3 & $\mathrm{MCl}$ & MC2 & MC3 \\
\hline Specific weight $\left(\mathrm{g} / \mathrm{cm}^{3}\right)$ & 2.86 & 2.44 & 2.26 & 2.10 & 2.64 & 2.60 & 2.44 & 2.66 & 2.55 & 2.50 \\
\hline Specimen weight (g) & 105.74 & 90.21 & 83.55 & 77.64 & 97.50 & 96.12 & 90.21 & 96.12 & 94.27 & 92.43 \\
\hline Fineness (Blaine) $\left(\mathrm{cm}^{2} / \mathrm{g}\right)$ & 2733 & 4677 & 5778 & 6686 & 3981 & 4398 & 4115 & 3696 & 3993 & 3999 \\
\hline $\begin{array}{l}\text { Water demand for standard } \\
\text { consistency }\end{array}$ & 24.86 & 32.86 & 38.29 & 43.71 & 29.43 & 31.43 & 32 & 29.71 & 31.43 & 32 \\
\hline
\end{tabular}

grounded to adequate fineness in a ball mill for $75 \mathrm{~min}$. When the diatomite and pumice were ground, they filled the plastic bags at the proportions given in Table 4 and were mixed by shaking for homogenity for a while. The mouth of plastic bags was closed and kept in dry place.

AP and MP were obtained from the waste storage site of the natural stone production plant and they had enough fineness as shown in Table 5.

2.2. Method. The cement pastes were mixed by using laboratory type mixer. The mixing procedure for the mortars was complying with TS EN 196-1 [18]. Initial and final setting times and standard consistency of cement pastes were determined using a Vicat apparatus and following TS EN 1963 procedure [19].

The prepared cement mortars were poured into the molds, having dimensions $40 \times 40 \times 160 \mathrm{~mm}^{3}$ that were shaked on a shock table to remove the entrapped air for 60 times for each half level of filled moulds. After casting and finishing, the molds were covered with plastic sheets and kept under the curing regime of $90 \%$ relative humudity and $20 \pm 2^{\circ} \mathrm{C}$ temperatures for $24 \mathrm{~h}$ and then demolded. After demolding, the specimens were cured under water maintained at $20^{\circ} \mathrm{C}$ for further 27 days.

First group tests were conducted on the specimens cured under water for determination of compressive and flexural strengths at the age of 7,28 , and 56 . The values presented in this work are the mean value of the three replicates.

A flexural strength test was carried out on three $40 \times$ $40 \times 160 \mathrm{~mm}^{3}$ prismatic specimens and then a compressive strength test was conducted on six pieces of prisms in accordance with TS EN 196-1 standard [18].

In assessing the effects of changing of clinker and pozzolan content on sulphate durability, tests performed according to ASTM 1012 [20] on ten Portland-pozzolan cements were conducted.

2.2.1. Scanning Electron Microscope (SEM) Application. The microstructures and morphologies of cements were evaluated by SEM (Scanning Electron Microscope) observations of mortar bars exposed to sodium sulphate solution for 90 days. For the SEM analyses, broken cement mortar parts after compression test were cut into slices of approximately $10 \mathrm{~mm}$ width, one side of which was ground flat. The specimens were then placed in vacuum dessicator for a minimum of three days. The specimen surfaces were then coated with gold.
The microstructures of different specimens were examined by JEOL 6060 LV Model Scanning Electron Microscope based on back scaretted mode.

2.2.2. Sulphate Concentration, Exposure, and Testing. After 28 days of curing, the mortar specimens were divided into two groups.

One group of specimens was continuously cured under water while the second group was placed in three tanks with the following sulphate concentrations:

(i) $1,500 \mathrm{mg} / \mathrm{L}, \mathrm{Na}_{2} \mathrm{SO}_{4}$,

(ii) $9,000 \mathrm{mg} / \mathrm{L}, \mathrm{Na}_{2} \mathrm{SO}_{4}$,

(iii) $13,500 \mathrm{mg} / \mathrm{L}, \mathrm{Na}_{2} \mathrm{SO}_{4}$.

The above exposure conditions represent moderate, severe, and very severe sulphate exposure conditions according to ACI 318-11 [21]. Solutions were renewed in periods of 14 days and mass changes were determined at the same periods.

Second group specimens were left for 90 days of the sodium sulphate exposure at the end of the 27 days of water curing before the determination of mass change, the length change, and the compressive and flexural strengths tests. The effect of sulphate concentration on the performance of plain and blended cements was evaluated by visual examination and measuring the reduction in compressive strength. Mass changes were calculated as the difference between the mass of saturated-surface dry specimen at any time and just before the sulphate exposure.

\section{Experimental Results and Discussion}

3.1. The Effects of Used Waste Materials on Standard Consistency Water Demand. Table 5 shows the relationship between the amount of additives and the amount of water required to produce a cement of standard consistency in the manufactured cements.

As shown in Table 5, more water was required to produce the standard consistency in the DP blended DC1, DC2, and DC3 cements, AP blended AC1, AC2, and AC3 cements, and MP blended MC1, MC2, and MC3 cements that was directly proportionate to the amounts of additive used.

According to Table 5, the most water was required by the DP blended cements. This may be due to the porous microstructure and specific gravity of the DPs. As the specific gravity of DPs is lower than other materials, volume of the DP 
TABLE 6: Setting time values and volume expansion values of cements.

\begin{tabular}{lcccccccccc}
\hline \multirow{2}{*}{ Setting times } & \multicolumn{1}{c}{ Cements codes } \\
& RC & DC1 & DC2 & DC3 & AC1 & AC2 & AC3 & MC1 & MC2 & MC3 \\
\hline Initial setting times (hours:min) & $3: 40$ & $2: 36$ & $2: 32$ & $2: 38$ & $2: 43$ & $2: 34$ & $2: 18$ & $2: 32$ & $2: 23$ & $2: 18$ \\
Final setting time (hours:min) & $4: 05$ & $3: 01$ & $3: 12$ & $3: 03$ & $3: 23$ & $3: 12$ & $2: 54$ & $2: 57$ & $2: 48$ & $2: 44$ \\
Volume expansion values $(\mathrm{mm})$ & 1 & 1 & 0 & 0 & 0 & 0 & 0 & 1.5 & 1 & 1 \\
\hline
\end{tabular}

TABLE 7: Chemical analysis results, Blaine values, and specific weight of blended cements.

\begin{tabular}{|c|c|c|c|c|c|c|c|c|c|c|c|}
\hline & \multicolumn{10}{|c|}{ Cements codes } & \multirow{2}{*}{ TS EN 197-1 } \\
\hline & $\mathrm{RC}$ & $\mathrm{DCl}$ & DC2 & DC3 & $\mathrm{ACl}$ & $\mathrm{AC} 2$ & AC3 & $\mathrm{MCl}$ & MC2 & MC3 & \\
\hline \multicolumn{12}{|c|}{ Chemical constituents (\%) } \\
\hline $\mathrm{SiO}_{2}$ & 19.20 & 30.99 & 37.42 & 42.40 & 27.16 & 28.19 & 30.61 & 23.71 & 22.08 & 20.58 & \\
\hline $\mathrm{Al}_{2} \mathrm{O}_{3}$ & 4.23 & 5.48 & 5.38 & 5.22 & 6.50 & 6.71 & 8.1 & 5.7 & 5.33 & 5.08 & \\
\hline $\mathrm{Fe}_{2} \mathrm{O}_{3}$ & 3.44 & 5.82 & 5.86 & 5.89 & 6.96 & 7.96 & 9.8 & 5.7 & 5.22 & 4.86 & \\
\hline $\mathrm{CaO}$ & 58.6 & 51.8 & 50.0 & 48.4 & 52.0 & 51.2 & 48.5 & 54.6 & 55.2 & 55.6 & \\
\hline $\mathrm{MgO}$ & 3.00 & 3.81 & 3.19 & 2.45 & 4.53 & 4.20 & 4.1 & 4.2 & 3.46 & 2.70 & \\
\hline $\mathrm{SO}_{3}$ & 3.18 & 2.37 & 2.18 & 1.97 & 2.41 & 2.81 & 2.1 & 2.6 & 2.41 & 2.30 & $<4.0$ \\
\hline Free $\mathrm{CaO}$ & 0.89 & 0.50 & 0.44 & 0.34 & 0.56 & 0.44 & 0.4 & 0.7 & 0.54 & 0.40 & \\
\hline $\mathrm{CI}$ & 0.001 & 0.004 & 0.005 & 0.004 & 0.005 & 0.013 & 0.005 & 0.006 & 0.007 & 0.007 & $<0.10$ \\
\hline \multicolumn{12}{|c|}{ Property } \\
\hline Specific density $\left(\mathrm{g} / \mathrm{cm}^{3}\right)$ & 2.86 & 2.44 & 2.26 & 2.10 & 2.64 & 2.60 & 2.44 & 2.66 & 2.55 & 2.50 & \\
\hline Blaine values $\left(\mathrm{cm}^{2} / \mathrm{g}\right)$ & 2733 & 4677 & 5778 & 6686 & 3981 & 4398 & 4115 & 3696 & 3993 & 3999 & \\
\hline Mixing water $(\mathrm{g})$ & 235 & 272 & 285 & 337 & 261 & 275 & 286 & 250 & 262 & 285 & \\
\hline Mixing water (\%) & 52 & 60 & 63 & 75 & 58 & 61 & 64 & 56 & 58 & 63 & \\
\hline
\end{tabular}

blended in the cements would be higher, thus increasing the amount of water required for standard consistency.

Another reason for the increase in the water requirement with increased amounts of AP and MP is the existence of more materials due to the rational increase of the substitute materials in terms of weight in total amount of bounding materials in the mix. Therefore, the existing porous structure of these materials is also involved in further amount of composition of cement. Thus, some of the water added for standard consistency is absorbed and stored within the pore structure of these materials.

\subsection{The Effects of Used Waste Materials on Setting Time.} Table 6 shows initial and final setting periods for ten cement types made of DP, PP, AP, MP, FA, and clinker. It was seen that setting periods of all cements were in accordance with the ultimate values specified in TS EN 197-1 [22].

Generally, in all-blended cements, initial setting periods show a tendency to decrease with increased use of waste material additives. A similar situation is also valid for the completion of setting. The shortest initial setting period was recorded as 2 hours and 18 minutes in 30\% AP and MP blended AC 3 and MC 3 cements.

When DP, MP, and AP are examined in terms of the setting periods, it is observed that AP blended cements initiate and complete setting later than DP and MP cements.
However, initial and complete setting periods of MP and DP blended cements show approximately similar values. Another point of note is that additive ratio and setting period in DP blended cements increase directly proportionally to each other, while the exact opposite occurs in MP and AP blended cements. The relationship between the increase in the additive ratio and setting period in the DP blended cements may be explained by the transfer of normal consistency water from the pores and its diffusion into the cement paste [17].

\subsection{The Effects of Used Waste Materials on Volumetric Expan-} sion. Table 6 shows the setting periods together with the volumetric expansion test results for the cements made of DP, PP, AP, MP, and FA. As shown, the obtained data was in accordance with the standards because the expansion volumes are below the ultimate value specified in TS EN 197-1 [22]. Therefore, the additives used could be said to make the desired contribution in terms of the volume expansion.

3.4. The Effects of Used Waste Materials on Specific Weight. Blaine values and specific density of blended cements are shown in Table 7. Specific densities of the cements show a decrease according to the rational increase in the DP, AP, and MP amounts in the cements. Only the specific gravity of clinker and gypsum blended RC cement (96\% clinker, $4 \%$ gypsum) is higher than that of the AP, MP, and DP blended 
TABLE 8: Compressive and flexural strength data of the specimens which were cured for 7, 28, or 56 days.

\begin{tabular}{|c|c|c|c|c|c|c|c|c|c|c|c|}
\hline \multirow{2}{*}{ Experiments } & \multirow{2}{*}{ Specimen ages (days) } & \multicolumn{10}{|c|}{ The specimens exposed to water } \\
\hline & & $\mathrm{RC}$ & $\mathrm{DC1}$ & $\mathrm{DC} 2$ & DC3 & $\mathrm{AC} 1$ & $\mathrm{AC} 2$ & AC3 & $\mathrm{MC1}$ & MC2 & MC3 \\
\hline \multirow{3}{*}{ Compressive strength $\left(\mathrm{N} / \mathrm{mm}^{2}\right)$} & 7 & 28.5 & 27.1 & 26.05 & 17.41 & 20.0 & 16.0 & 11.7 & 18.50 & 17.2 & 12.90 \\
\hline & 28 & 47.4 & 41.4 & 41.00 & 31.55 & 32.2 & 26.2 & 19.2 & 31.80 & 27.1 & 19.75 \\
\hline & 56 & 49.7 & 43.7 & 43.85 & 34.25 & 34.9 & 28.7 & 22.0 & 34.55 & 29.7 & 22.50 \\
\hline \multirow{3}{*}{ Flexural strength $\left(\mathrm{N} / \mathrm{mm}^{2}\right)$} & 7 & 4.31 & 4.27 & 4.51 & 3.69 & 3.16 & 3.11 & 2.42 & 3.1 & 3.08 & 2.35 \\
\hline & 28 & 7.56 & 7.63 & 6.30 & 6.02 & 5.84 & 4.80 & 3.60 & 4.8 & 3.90 & 2.95 \\
\hline & 56 & 8.59 & 8.37 & 7.55 & 6.80 & 6.61 & 5.40 & 4.70 & 5.6 & 5.32 & 4.79 \\
\hline
\end{tabular}

TABLE 9: Compressive and flexural strength values of cement mortar bars kept in sodium sulphate.

\begin{tabular}{|c|c|c|c|c|c|c|c|c|c|c|c|}
\hline \multirow{2}{*}{ Experiments } & \multirow{2}{*}{ Solution levels $(\mathrm{mg} / \mathrm{L})$} & \multicolumn{10}{|c|}{ The specimens exposed to $\mathrm{Na}_{2} \mathrm{SO}_{4}$ solution } \\
\hline & & $\mathrm{RC}$ & $\mathrm{DC} 1$ & DC2 & DC3 & $\mathrm{ACl}$ & AC2 & $\mathrm{AC} 3$ & MC1 & MC2 & MC3 \\
\hline \multirow{3}{*}{ Compressive strength $\left(\mathrm{N} / \mathrm{mm}^{2}\right)$} & 1500 & 44.7 & 36.7 & 32.49 & 12.63 & 34.15 & 17.69 & 17.12 & 30.82 & 19.61 & 17.36 \\
\hline & 9000 & 40.5 & 34.4 & 21.85 & 18.53 & 27.42 & 26.59 & 15.2 & 29.49 & 23.51 & 15.95 \\
\hline & 13500 & 37.1 & 25.6 & 21.52 & 11.13 & 27.17 & 22.18 & 21.93 & 30.99 & 18.11 & 17.95 \\
\hline \multirow{3}{*}{ Flexural strength $\left(\mathrm{N} / \mathrm{mm}^{2}\right)$} & 1500 & 7.56 & 6.44 & 5.95 & 4.82 & 6.27 & 6.25 & 5.95 & 6.14 & 6.16 & 6.00 \\
\hline & 9000 & 7.43 & 4.71 & 4.8 & 4.16 & 6.69 & 6.71 & 6.5 & 4.37 & 6.5 & 5.84 \\
\hline & 13500 & 7.33 & 4.5 & 4.78 & 3.84 & 7.17 & 6.67 & 5.91 & 6.46 & 6.04 & 5.95 \\
\hline
\end{tabular}

cements. Another comparison is that the specific gravities of MP and AP blended cements show approximately similar values, while DP blended cements seem to have lower specific gravity than others, due to the low specific gravity of DP.

3.5. The Effects of Used Waste Materials on Chemical Specifications of Cements. Table 7 shows the chemical compositions of DP, PP, AP, MP, and FA blended cements. Numeric data for the chemical characteristics of the cements are in accordance with the ultimate values specified in the table. In other words, all of the various types of blended cements conform to TS EN 197-1 in terms of the chemical constituents [22].

3.6. The Effects of Used Waste Materials on Water Requirements of Cement Mortar. Table 7 shows the water requirements of the DP, AP, MP, PP, and FA blended cements and the control cement mortars, determined form the pour test specified in ASTM C 109. The amount of water required to achieve stable consistency in the manufactured cements $(110 \pm 5 \%$ pouring should be ensured according to ASTM C 109) is similar to the amount for the standard consistency [23]. Therefore, the factors affecting the water requirement for standard consistency also have an effect on these cement mortars.

As shown in the relationship between additive ratio and mortar water in Table 7, mortar water shows an increase parallel with the increase in the additive ratio of the materials blended in the cements. There are two reasons for this; the first is that clinker has a lower specific gravity than other materials, and the second is that the waste materials used have a more porous structure than the clinker particles.

The effect of the specific surface area of the cement on the required water is similar to its effect on the quantity of water for standard consistency. This is clearly demonstrated in the relationship between cement fineness and standard consistency water, shown in Table 7.

DP mortars required more water than the AP and MP mortars, which had similar water requirements. This could be explained by the lower specific gravity of DPs compared to the AP and MPs. As the blending process is based on weight, more DPs will be used for the same additive ratio and this means more mortar water will be needed. In addition, the water-increasing effect of the porous structure of DPs should also be considered.

\subsection{The Effects of Used Waste Materials on Flexural and Compressive Strength}

3.7.1. Flexural Tensile Strength. The specimens were subjected to flexural tensile strength tests in accordance with TS EN 196-1 [18]. Tables 8 and 9, respectively, show the compressive strength values together with the numeric data for cement specimens cured in water for 56 days and kept in sodium sulphate $\left(\mathrm{Na}_{2} \mathrm{SO}_{4}\right)$ solution for 90 days.

According to the numeric data obtained after water curing cements for 7, 28, and 56 days and after the flexural tensile strength test, the following were seen:

(i) On day 7,20\% DP blended DC2 specimen had higher flexural tensile strength than the reference cement RC $\left(4.51 \mathrm{~N} / \mathrm{mm}^{2}\right)$.

(ii) On day 28, the highest flexural tensile strength was obtained from the $10 \%$ DP blended specimens $\left(7.63 \mathrm{~N} / \mathrm{mm}^{2}\right)$.

(iii) On day 56, the highest flexural tensile strength was obtained from the 10\% DP blended DC1 specimen.

(iv) At all ages, the AP and MP specimens showed similar values for the same additive ratios. 
(v) The lowest flexural tensile strength was obtained from 30\% MP blended MC3 specimens $\left(2.35-2,95 \mathrm{~N} / \mathrm{mm}^{2}\right)$ on days 7 and 28 and from $30 \%$ AP blended AC3 specimen $\left(4.70 \mathrm{~N} / \mathrm{mm}^{2}\right)$ on day 56 . In general, flexural tensile strength in DP, AP, and MP blended cements decreased with increasing additive ratios.

3.7.2. Compressive Strength. Specimens were cured for 7, 28, or 56 days in water and for 90 days in $\mathrm{Na}_{2} \mathrm{SO}_{4}$ solution and were then subjected to compressive strength tests in accordance with TS EN 196-1 [18]. Tables 8 and 9 show the compressive strength data of the specimens kept in water and $\mathrm{Na}_{2} \mathrm{SO}_{4}$ solution, respectively.

The compressive strength results for the specimens cured in water showed the following:

(i) No high compressive strength value was obtained from the reference specimens (RC) on days 7, 28, or 56.

(ii) The highest compressive strength was obtained from the DP blended group on days 7,28 , and 56 (resp., $27.1 \mathrm{~N} / \mathrm{mm}^{2}$ for $10 \% \mathrm{DP}, 26.05 \mathrm{~N} / \mathrm{mm}^{2}$ for $20 \%$ $\mathrm{DP}$, and $17.41 \mathrm{~N} / \mathrm{mm}^{2}$ for $30 \% \mathrm{DP}$ on day 7 , and $41.4 \mathrm{~N} / \mathrm{mm}^{2} ; 41.00 \mathrm{~N} / \mathrm{mm}^{2}$; and $31.55 \mathrm{~N} / \mathrm{mm}^{2}$ on day 28).

(iii) The highest strength was obtained from the $10 \%$ DP blended DC1 specimen on days $7\left(27.1 \mathrm{~N} / \mathrm{mm}^{2}\right)$, $28\left(41.4 \mathrm{~N} / \mathrm{mm}^{2}\right)$, and $56\left(43.7 \mathrm{~N} / \mathrm{mm}^{2}\right)$ and from the $20 \%$ DP blended DC2 specimen on day 56 $\left(43.85 \mathrm{~N} / \mathrm{mm}^{2}\right)$. After sufficient water curing, DC may act such as silica fume in blended cement together with pumice and fly ash at the ratio of $10 \%$, because of high content $\mathrm{SiO}_{2}$ [24].

(iv) The lowest compressive strength was obtained from the $30 \%$ AP blended AC3 specimen on days 7, 28, and 56.

(v) As in the previous flexural tensile strength tests, compressive strength was found to decrease with increased additive ratios. Such a decrease could be explained by the internal structures of the materials becoming more porous with increasing use of additives.

\subsection{The Effect of Sulphate on Flexural Strength and Compressive Strength}

3.8.1. The Effect of Sulphate on Flexural Strength. Flexural strength tests of specimens kept in $\mathrm{Na}_{2} \mathrm{SO}_{4}$ solution for 90 days showed the following:

(i) After 90 days, the highest flexural tensile strength was obtained from $10 \%$ DP blended DC1 specimen among the specimens kept in the moderate effective solution (1500 mg/L Na $\mathrm{SO}_{4}$ ).

(ii) After 90 days, the highest flexural tensile strength was obtained from the AP-groups specimens among the specimens kept in severe $\left(9000 \mathrm{mg} / \mathrm{L} \mathrm{Na}_{2} \mathrm{SO}_{4}\right)$ or very severe effective solutions ( $13500 \mathrm{mg} / \mathrm{L} \mathrm{Na}_{2} \mathrm{SO}_{4}$ ).

(iii) The highest flexural tensile strength was obtained from $20 \%$ AP additive in the severe effective solution and from $10 \%$ AP additive in the very severe effective solution.

(iv) In all solution types, 30\% DP blended (DC3) specimen showed the lowest strength against sulphate, which may be due to the involvement of a more porous structure in the cement according to the amount of DP additive.

(v) Despite some exceptions, it may be concluded that additive ratios and flexural tensile strength are inversely related. In other words, an increase in the additive ratio causes a decrease in the flexural tensile strength.

\subsubsection{The Effect of Sulphate on Compressive Strength}

(i) As expected, in the compressive strength tests to determine the effect of sulphate, the compressive strength values of the specimens stored in $\mathrm{Na}_{2} \mathrm{SO}_{4}$ solution for 90 days were low compared to the strength values obtained from 28-day and 56-day replicate specimens cured in water. According to the compressive strength values of cement mortar bars kept in sodium sulphate for 90 days, it was seen that reference specimens (RC) showed the best performance in all solutions.

(ii) Among the specimens kept in the moderate effective solution $(1500 \mathrm{mg} / \mathrm{L})$, the highest strength against sulphate was $36.72 \mathrm{~N} / \mathrm{mm}^{2}$, recorded in the $10 \% \mathrm{DP}$ blended DC1 specimen.

(iii) Among the specimens kept in the severe effective solution $(9000 \mathrm{mg} / \mathrm{L})$, the highest strength against sulphate was again obtained from $10 \%$ DP blended DC1 specimen $\left(34.4 \mathrm{~N} / \mathrm{mm}^{2}\right)$, followed by $10 \% \mathrm{MP}$ and AP blended specimens.

Among the specimens kept in the very severe effective solution $(13500 \mathrm{mg} / \mathrm{L})$, the highest strength against sulphate was obtained from 10\% MP blended MC1 (approximately $31 \mathrm{~N} / \mathrm{mm}^{2}$ ) followed, respectively, by $10 \% \mathrm{AP}$ (AC1) and DP powder blended (DC1) specimens. The compressive strength results for ternary blended cement which included MP were similar with the findings of Agarwal and Gulati (2006) [14]. Similar results to these findings reported by Tosun et al. (2009) showed that, from the viewpoint of strength and durability, maximum limestone powder replacement with clinker on the production of concrete should not exceed $10 \%$, especially for the structures that are constructed in sulphate bearing environments in cold regions [25].

According to the test results, such a loss of strength in the specimens stored in sulphate could be explained by ettringite formation. Blended cements including both fly ash and natural pozzolan reduced the potential for the formation of ettringite due to the reduction in the quantity of calcium 
TABLE 10: Relative variation of compressive strength with effect of different concentration of solution $\mathrm{Na}_{2} \mathrm{SO}_{4}$.

\begin{tabular}{|c|c|c|c|c|c|c|c|c|c|c|}
\hline \multirow{2}{*}{ Property } & \multicolumn{10}{|c|}{ Specimen code } \\
\hline & $\mathrm{RC}$ & $\mathrm{DC} 1$ & $\mathrm{DC} 2$ & DC3 & $\mathrm{AC} 1$ & AC2 & AC3 & $\mathrm{MC1}$ & MC2 & MC3 \\
\hline $\begin{array}{l}\text { Loss of strength of specimens } \\
\text { kept in the less effective solution } \\
(\%)\end{array}$ & 10.0 & 16.0 & 26 & 63.0 & 2.0 & 38.4 & 22.0 & 10.8 & 34.0 & 22.8 \\
\hline $\begin{array}{l}\text { Loss of strength of specimens } \\
\text { kept in the severe effective } \\
\text { solution }(\%)\end{array}$ & 18.5 & 21.0 & 50 & 46.0 & 21.4 & 7.30 & 31.0 & 14.6 & 20.8 & 29.0 \\
\hline $\begin{array}{l}\text { Loss of strength of specimens } \\
\text { kept in the very severe effective } \\
\text { solution }(\%)\end{array}$ & 25.4 & 41.4 & 51 & 67.5 & 22.0 & 22.7 & 0.30 & 10.3 & 39.0 & 20.2 \\
\hline
\end{tabular}

hydroxide and $\mathrm{C}_{3} \mathrm{~A}[26]$. Gypsum could also cause reductions in hardness and strength. Gypsum was indicated not affecting the strength as much as ettringite. In addition, disruption in the hardened cement mortars, beginning with gypsum formation, resulted in hardness and strength loss, which became worse with expansion [27]. Relative variation of compressive strength with effect of different concentration of solution $\mathrm{Na}_{2} \mathrm{SO}_{4}$ is shown in Table 10 .

A research program conducted by Stephens and Carrasquillo (2000) recommended using the sulphate resistant Portland cements with a $\mathrm{C}_{3} \mathrm{~A}$ content of $4-5 \%$ in a high sulphate environment [28]. The amount of $\mathrm{C}_{3} \mathrm{~S}$ and $\mathrm{C}_{2} \mathrm{~S}$ also affects the performance of concrete depending on cement types under sulphate attack. Usually, as the amount of $\mathrm{C}_{3} \mathrm{~A}$ reduces, $\mathrm{C}_{3} \mathrm{~S} / \mathrm{C}_{2} \mathrm{~S}$ ratio increases and as this ratio increases, the amount of calcium hydroxide $(\mathrm{CH})$ produced by the hydrolysis of these two compounds increases. $\mathrm{CH}$ reacts with the sulphates attacking concrete producing gypsum. The produced gypsum will cause expansion and strength reduction by time in the already hardened concrete.

3.9. The Effects of Used Waste Materials on Length Change Tests. Specimens to be subjected to length change tests were chosen from specimens cured in water and which showed relatively good performance in the compressive strength tests. CEM I 42.5, 10, 20, and 30\%; DP blended (DC1, DC2, and DC3) specimens; $10 \%$ AP blended AC1; and 10\% MP blended $\mathrm{MCl}$ specimen mortar bars were cured in drying rooms with $23 \pm 1^{\circ} \mathrm{C}$ temperature and $50 \pm 5 \%$ relative humidity 13 weeks (125 days) in such a way that all specimens would be subjected to the same air circulation. Figure 1 shows the relationship between length change and age of the mortar bar specimens.

As shown in Figure 1, length change values followed a fluctuating course. The results show that length change values decreased with increased additive ratios in the DP group. After 125 days, the lowest length change value $(-0.079 \%)$ was found in the 30\% DP blended DC3 specimen. The highest length change value $(0.1371 \%)$ was found in the $10 \% \mathrm{MP}$ blended MC1 specimen. Therefore, the 30\% DC3 specimen, which has the highest DP content, showed lower length change value compared to, respectively, the $10 \%$ AP and MP blended $\mathrm{ACl}$ and $\mathrm{MCl}$ and the replicate specimen $\mathrm{RC}$, which all contained the lowest additive ratios.

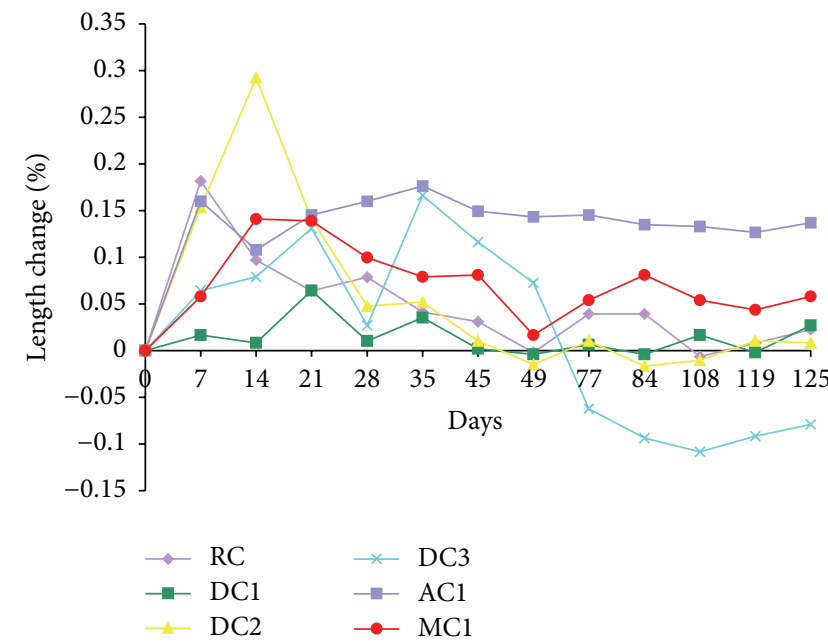

FIGURE 1: The relationship between length change and age of the mortar bar specimens.

In conclusion, the use of increased DP content could be said to decrease the length change of the cement. The fluctuating course of length change observed in the specimens is estimated to be derived from the curing facilities. As the amount of water used in the tests was determined by the "water requirement of the cement" test, the pores within the cement materials were completely waterlogged. In the advancing ages, it will be appropriate to control the environmental factors in a standardized way and to monitor the length change during the consumption of water through evaporation and hydration. More detailed studies are required to accomplish this.

3.10. Results of Scanning Electron Microscope (SEM). SEM examinations were carried out on blended cement (obtained by replacing DP, AP, and AP with clinker, one by one at the percent of 10,20, and 30) mortar bars that had been exposed to a very severe sodium sulphate solution $(13500 \mathrm{mg} / \mathrm{L})$ for 90 days.

The reactions between $5 \%$ gypsum and water used in the cement together with $\mathrm{C}_{4} \mathrm{AF}$ and, especially, $\mathrm{C}_{3} \mathrm{~A}$ cause ettringite and formation of products such as calcium, alumino, and 


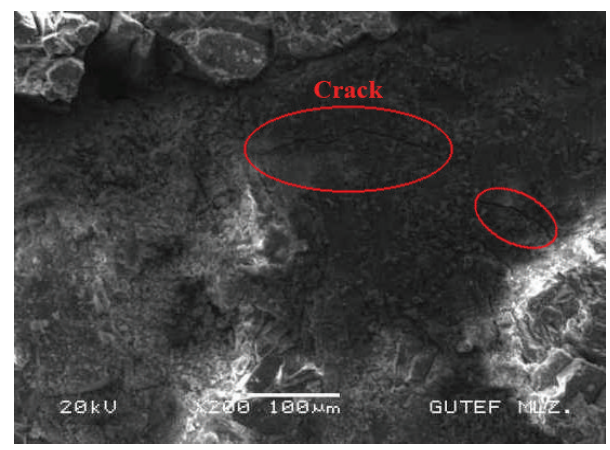

FIGURE 2: The SEM views obtained from the reference mortar after sulphate exposure.

monosulfhydrate. Formation of the $\mathrm{C}_{4} \mathrm{ASH}_{12}$ crystal causes slight expansion in the cement paste. These crystals are plateshaped and have a metastable state. As the manufactured specimens were left in an environment with very severe sulphate, the material forming on the specimens stabilized and turned into hexagonal and bar-shaped ettringite crystals. As shown in Figure 2, the formation of ettringite causes expansion thus initiating cracks. This situation is called "sulphate attack" in the literature $[3,4,6,7,28,29]$.

The SEM images of the DP blended specimens suggest that sulphate solution had infiltrated these structures due to the porous internal structure and facilitated the formation of harmful compounds, starting from the pores, which reduced the resistance of the specimens against the harmful effects of sulphate attack.

The results obtained from the reference mortar bars showed continuous local cracks of around $1 \mu \mathrm{m}$ in width. As will be discussed below while discussing the SEM views of other samples, these cracks are considered to be due to the adverse effects of sulphate on hardened cement mortar (Figure 2).

The microstructures (SEM) of 10, 20, and 30\% DP blended cement mortar bars after very severe sulphate exposure for 90 days are given, respectively, in Figures 3(a), 3(b), and 3(c).

The SEM views show that partially less cracking occurred in the 10\% DP mixed samples than in the reference samples (Figure 3(a)), although they had a more porous microstructure than the reference samples. It is also seen that partial but mild cracking occurs in parts if the samples are blended at $20 \%$ (Figure 3(b)). The study indicated further that the 30\% DP blended samples exhibited an even more porous structure and suffered even more intense cracking (Figure 3(c)).

The microstructures (SEM) of the 10, 20, and $30 \%$ waste AP blended cement mortar bars after being exposed to very severe sulphate solution exposure for 90 days are given, respectively, in Figures 4(a), 4(b), and 4(c).

An examination of the AP blended samples reveals similar reactions to the DP blended cement mortar samples. The $10 \%$ AP blended samples exhibit partial cracks in certain sections, while the $20 \%$ AP blended samples exhibit a more intense and continuous cracking pattern (Figures 4(a) and $4(\mathrm{~b}))$. In the case of the $30 \%$ AP blended cement samples, the sulphate causes even more cracking and increased porosity (Figure 4(c)).

The microstructures (SEM) of 10, 20, and 30\% waste MP blended cement mortar bars after being exposed to very severe sulphate solution for 90 days are given, respectively, in Figure 5.

When the SEM microstructures of the waste MP blended cement mortar samples that have been exposed to very severe sodium sulphate solution $(13500 \mathrm{mg} / \mathrm{L})$ for 90 days are examined, it can be seen that the samples with $10 \%$ waste MP content exhibited a relatively more compact structure and smaller cracks (Figure 5(a)). In the case of the $20 \%$ waste MP blended samples, no more cracks were apparent, but a partly porous structure was observed (Figure 5(b)). In the case of the $30 \%$ blend, on the other hand, relatively more intense and continuous cracks appeared compared to those in the 10 and $20 \%$ waste MP blended cement samples (Figure 5(c)).

According to results of this study, which aims to provide a clearer insight into the effects of sulphate waste material blended cement mortar bars via SEM microstructure views, one can conclude that the strength values of the samples exposed to sulphate and crack formation are interrelated. It was found that an increase in the amount of waste material causes a decrease in strength values. Microstructure analyses illustrate clearly the formation of 1-3 $\mu$ m wide, deep cracks. On the other hand, an examination of the SEM microstructures reveals that cement types with less Blaine that do mostly not pass through the sieve were more porous. As a result, it was considered that sulphate ingress occurs faster and more readily in the event of high porosity, which results in expansion and, consequently, a decrease in strength values. A less porous structure is considered to play an important role in a relatively limited strength loss in the case of the $10 \%$ waste $\mathrm{MP}$ and AP blended cement mortar samples.

\section{Conclusions and Suggestions}

Within the scope of this study, blended cements were manufactured using FA obtained from the chimneys of thermal plants; PP and DP obtained from the bimsblock factory and open mine plants, respectively; and AP and MPs obtained during the production of MP and AP paving stones. CEM I 42.5 and the reference cement RC were compared and the results are as follows:

(1) Substitution of certain amounts of the cement with AP, DP, and MPs increases the amount of water required to achieve a standard consistency in proportion to the amounts of these materials used. The observed increase is a linear function of the additive ratios. In addition, the water required for standard consistency of the DP blended cements was slightly higher than that of the MP and AP cements, and the water requirements of the AP or MP blended cements for standard consistency were similar.

(2) The use of DP, AP, and MP was found to reduce the initiation and completion of setting according to the amount used in the cement mix. 


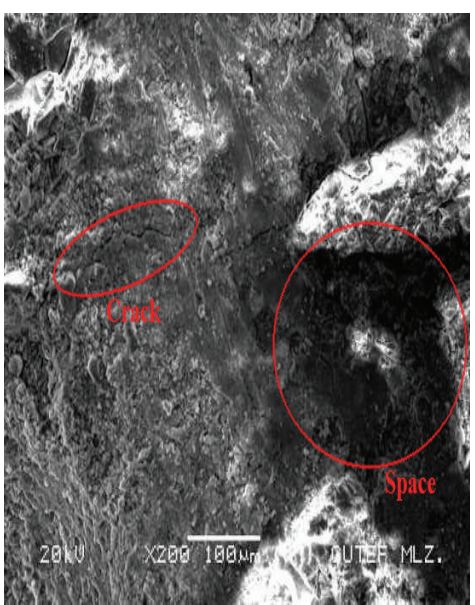

(a)

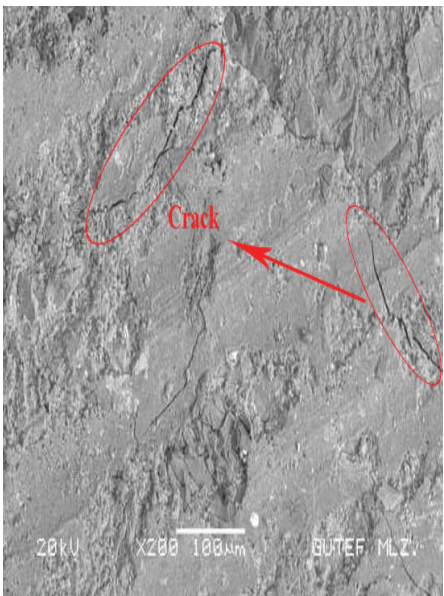

(b)

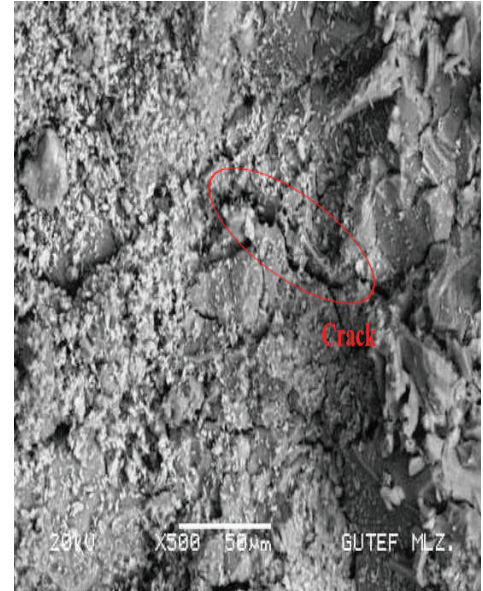

(c)

Figure 3: (a) The SEM views obtained from the DC1 mortar after sulphate exposure. (b) The SEM views obtained from the DC2 mortar after sulphate exposure. (c) The SEM views obtained from the DC3 mortar after sulphate exposure.

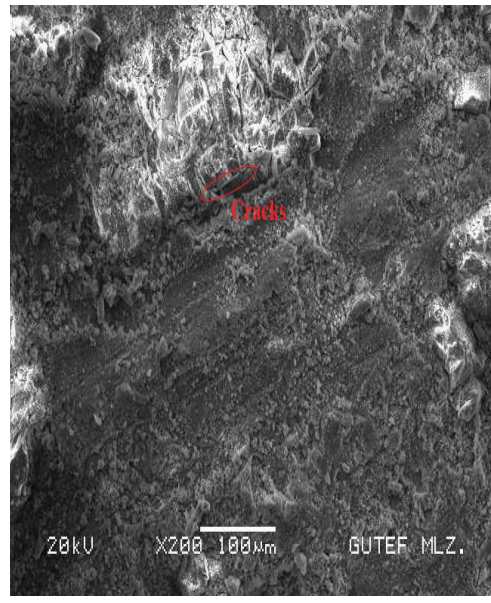

(a)

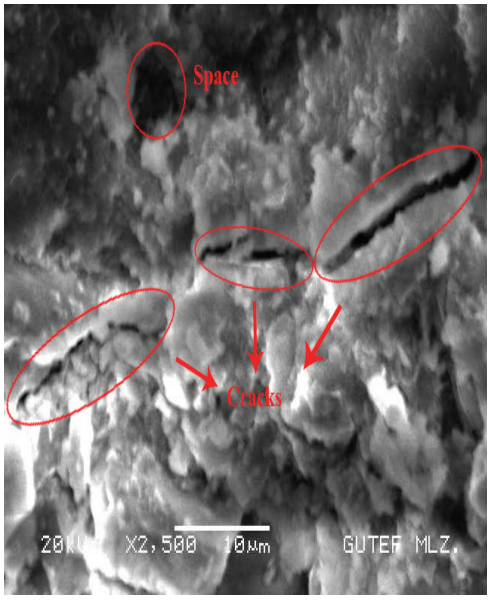

(b)

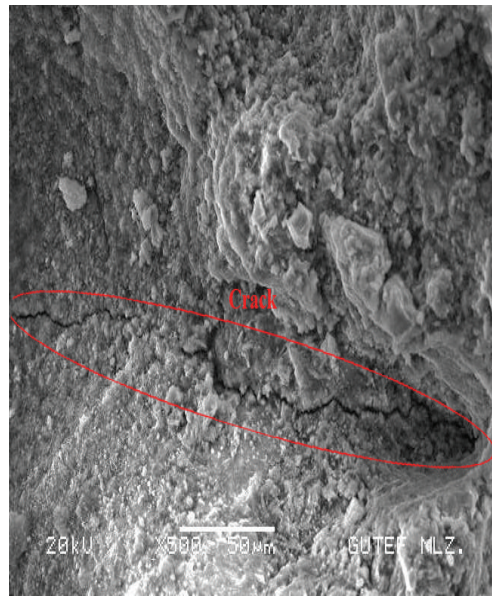

(c)

Figure 4: (a) SEM microstructures of waste AP powder blended cement AC1 mortar bars after exposure to very severe $(13500 \mathrm{mg} / \mathrm{L}) \mathrm{Na}_{2} \mathrm{SO}{ }_{4}$ solution for 90 days. (b) SEM microstructures of waste AP powder blended cement AC2 mortar bars after exposure to very severe (13500 mg/L) $\mathrm{Na}_{2} \mathrm{SO}_{4}$ solution for 90 days. (c) SEM microstructures of waste AP powder blended cement AC3 mortar bars after exposure to very severe $(13500 \mathrm{mg} / \mathrm{L}) \mathrm{Na}_{2} \mathrm{SO}_{4}$ solution for 90 days.

(3) Test results met the condition that standard volume expansion should be less than $10 \mathrm{~mm}$. An increase in the DP, AP, and MP ratios did not have a negative effect on the volume expansion.

(4) A decrease was observed in the specific gravities of the cements with increased use of DP, AP, and MP. DP blended cements had the lowest specific gravity due to the low specific gravity of DPs.

(5) The chemical compositions of the manufactured cements were in accordance with the proportions specified in TS EN 197-1 [22].

(6) Increased use of DP, AP, and MP directly increased the water requirements of mortars. The increase was slightly greater in the DP blended cements, while the water requirements of the $\mathrm{AP}$ and $\mathrm{MP}$ blended cements were similar to each other.

(7) Increased amounts of DP, AP, and MP in the cements reduced the compressive strength of the specimens. In the advancing ages, considerable increases were observed in the compressive strength values due to the pozzolanic features of the materials. The $10 \%$ and 20\% DP blended cements showed similar compressive strength characteristics to the RC reference cement. However, during the 28-day compressive strength tests, only the $10 \%$ and $20 \%$ DP blended cements met the specification of pozzolanic cement type 32.5 (CEM IV B) according to standard TS EN 197-1 [22]. A similar inverse relationship between 


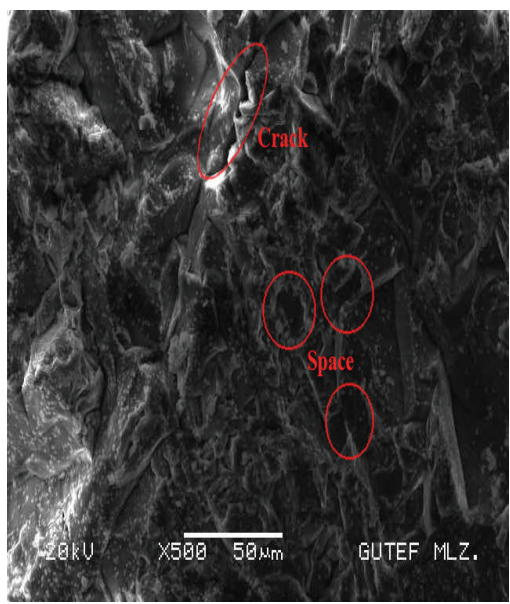

(a)

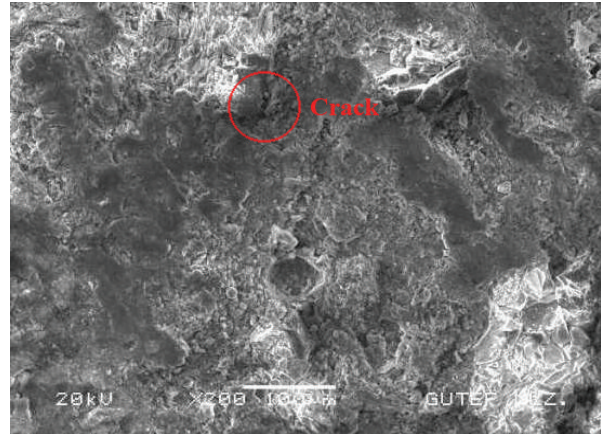

(b)

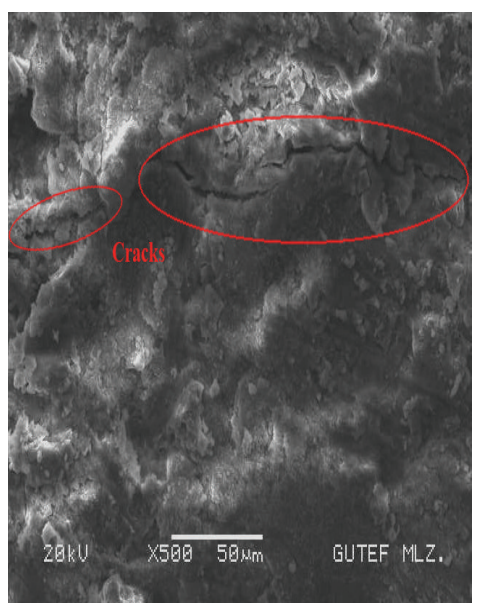

(c)

FiguRE 5: (a) SEM microstructures of waste MP blended cement MP1 mortar bars after exposure to very severe $(13500 \mathrm{mg} / \mathrm{L}) \mathrm{Na}_{2} \mathrm{SO}_{4}$ solution for 90 days. (b) SEM microstructures of waste MP blended cement MP2 mortar bars after exposure to very severe $(13500 \mathrm{mg} / \mathrm{L}) \mathrm{Na}_{2} \mathrm{SO}{ }_{4}$ solution for 90 days. (c) SEM microstructures of waste MP blended cement MP3 mortar bars after exposure to very severe (13500 mg/L) $\mathrm{Na}_{2} \mathrm{SO}_{4}$ solution for 90 days.

additive ratio and compressive strength was also observed in the sulphate solutions, but increasing the amount of $\mathrm{Na}_{2} \mathrm{SO}_{4}$ reduced the compressive strength of the specimens. Specimens with lower additive ratios (cements blended with $10 \%$ additive) gave better results in these tests. In conclusion, compressive strength was lower in all additive groups compared to the specimens cured in water.

(8) Increased additive ratio also reduced the flexural tensile strength of the cements. Here, specimens with low additive ratios (10\% and 20\%) showed better results both in specimens cured in sulphate solutions and in specimens cured in water. Sulphate attack was low in the AP and MP blended specimens in the sulphate solutions and better results were achieved compared to the DP blended specimens.

(9) Length change tests were carried out with CEM I 42.5 (RC); 10\%, 20\%, and 30\% DP blended DC1, DC2, and DC3 specimens; and 10\% AP (AC1) and 10\% MP blended (MC1) specimens. Test results show that the addition of diatomite powder reduces the length change of the cement according to the increase in the additive ratio.

\section{Conflict of Interests}

The authors declare that there is no conflict of interests regarding the publication of this paper.

\section{Acknowledgments}

This study was prepared by using master thesis titled "An investigation on producing of blended cement resistant to chemical effects" supervised by Dr. Emre Sancak. The authors would like to thank Suleyman Demirel University, Scientific Research Projects Management Unit (BAP), through Project 
no. 1622-YL-08 for their financial support. This research was partially supported by Turkish Cement Manufacturers' Association, under Iz Birakanlar Scholarship Programme. Besides, special thanks are due to Dr. Yakup Umucu, Dr. Ahmet Güral, and Dr. Yllmaz Koçak for providing support and assistance during the preparation of materials and examination of samples. The authors want to thank all the technical staff of the laboratories at Afyon CIMSA and Isparta GOLTAS Cement Factories and ISBAS Bimsblok Factory, and ISTEM Company in Isparta for providing support and assistance during the experimental programme.

\section{References}

[1] P. Chindaprasirt, P. Kanchanda, A. Sathonsaowaphak, and H. T. Cao, "Sulfate resistance of blended cements containing fly ash and rice husk ash," Construction and Building Materials, vol. 21, no. 6, pp. 1356-1361, 2007.

[2] M. Collepardi, "A state-of-the-art review on delayed ettringite attack on concrete," Cement and Concrete Composites, vol. 25, no. 4-5, pp. 401-407, 2003.

[3] K. R. Lauer, "Classification of concrete damage caused by chemical attack," Materials and Structures, vol. 23, no. 3, pp. 223-229, 1990.

[4] N. Shanahan and A. Zayed, "Cement composition and sulfate attack. Part I," Cement and Concrete Research, vol. 37, no. 4, pp. 618-623, 2007.

[5] ACI Committee, "Guide to durable concrete, American Concrete Institute manual of concrete practice, part I: materials and properties of concrete," ACI Committee Report 201.2R, ACI Committee, 2008.

[6] R. E. Rodríguez-Camacho and R. Uribe-Afif, "Importance of using the natural pozzolans on concrete durability," Cement and Concrete Research, vol. 32, no. 12, pp. 1851-1858, 2002.

[7] P. K. Mehta, "Mechanism of sulfate attack on portland cement concrete-another look," Cement and Concrete Research, vol. 13, no. 3, pp. 401-406, 1983.

[8] A. A. Rasheeduzzafar, O. Abduljauwad, and M. Maslehuddin, "Magnesium-sodium sulphate attack in plain and blended cements," Journal of Material and Civil Engineering, vol. 6, no. 2, pp. 201-222, 1994.

[9] V. M. Malhotra, Supplementary Cementing Materials for Concrete, CANMET, Canadian Government Publishing Centre, 1987.

[10] S. Türkel, B. Felekoğlu, and S. Dulluç, "Influence of various acids on the physico-mechanical properties of pozzolanic cement mortars," Sadhana, vol. 32, no. 6, pp. 683-691, 2007.

[11] T. Schmidt, B. Lothenbach, M. Romer, J. Neuenschwander, and K. Scrivener, "Physical and microstructural aspects of sulfate attack on ordinary and limestone blended Portland cements," Cement and Concrete Research, vol. 39, no. 12, pp. 1111-1121, 2009.

[12] D. Chen, C. Du, X. Feng, and F. Ouyang, "An elastoplastic damage constitutive model for cementitious materials under wetdry cyclic sulfate attack," Mathematical Problems in Engineering, vol. 2013, Article ID 562410, 7 pages, 2013.

[13] H. Y. Aruntaş, M. Gürü, M. Dayı, and I. Tekin, "Utilization of waste marble dust as an additive in cement production," Materials and Design, vol. 31, no. 8, pp. 4039-4042, 2010.
[14] S. K. Agarwal and D. Gulati, "Utilization of industrial wastes and unprocessed micro-fillers for making cost effective mortars," Construction and Building Materials, vol. 20, no. 10, pp. 999-1004, 2006.

[15] A. Ergün, "Effects of the usage of diatomite and waste marble powder as partial replacement of cement on the mechanical properties of concrete," Construction and Building Materials, vol. 25, no. 2, pp. 806-812, 2011.

[16] Ş. Özkan, An investigation on producing of blended cement resistant to chemical effects [M.S. thesis], The Graduate School of Natural and Applied Sciences, Suleyman Demirel University, Isparta, Turkey, 2009.

[17] H. Y. Aruntaş, Usability of diatomaceous earth as a pozzolan in cementitious systems [Ph.D. thesis], The Graduate School of Natural and Applied Sciences, Gazi University, Ankara, Turkey, 1996.

[18] Turkish Standards Institute, TS EN 196-1, Methods of Testing Cement-Part 1: Determination of Strength, Turkish Standards Institute, Ankara, Turkey, 2009.

[19] Turkish Standards Institute, "Methods of testing cement-part 3: determination of setting times and sondness," Tech. Rep. TS EN 196-3, Turkish Standards Institute, Ankara, Turkey, 2010.

[20] ASTM International, "Standard test method for length change of hydraulic-cement mortars exposed to a sulfate solution," in Annual Book of ASTM Standards, ASTM C 1012M-13, ASTM International, 2013.

[21] ACI 318-11, Building Code Requirements for Structural Concrete. ACI Manual of Concrete Practice Part 3: Use of Concrete in Buildings Design, Specifications, and Related Topics Detroit, ACI, Detroit, Mich, USA, 2011.

[22] Turkish Standards Institute, "Cement-part 1: composition, specifications and conformity criteria for common cements," Tech. Rep. TS EN 197-1, Turkish Standards Institute, Ankara, Turkey, 2012.

[23] ASTM C 109M-13, "Standard test method for compressive strength of hydraulic cement mortar," in Annual Book of ASTM Standards, ASTM C 109M-13, 2013.

[24] S. Türkel and Y. Altuntaş, "The effect of limestone powder, fly ash and silica fume on the properties of self-compacting repair mortars," Sadhana, vol. 34, no. 2, pp. 331-343, 2009.

[25] K. Tosun, B. Felekoğlu, B. Baradan, and İ. A. Altun, "Portland limestone cement part II-sulphate resistance," Teknik Dergi, vol. 310, pp. 4737-4757, 2009.

[26] M. Şahmaran, O. Kasap, K. Duru, and İ. Ö. Yaman, "Effects of mix composition and water-cement ratio on the sulfate resistance of blended cements," Cement and Concrete Composites, vol. 29, no. 3, pp. 159-167, 2007.

[27] S. U. Al-Dulaijan, M. Maslehuddin, M. M. Al-Zahrani, A. M. Sharif, M. Shameem, and M. Ibrahim, "Sulfate resistance of plain and blended cements exposed to varying concentrations of sodium sulfate," Cement and Concrete Composites, vol. 25, no. 4-5, pp. 429-437, 2003.

[28] J. B. Stephens and R. L. Carrasquillo, "Evaluating performance based test and specifications for sulphate resistance in concrete," Research Report 1706-3, University of Texas at Austin, Austin, Tex, USA, 2000.

[29] T. Y. Erdoğan, Concrete, METU Press, Ankara, Turkey, 2003. 

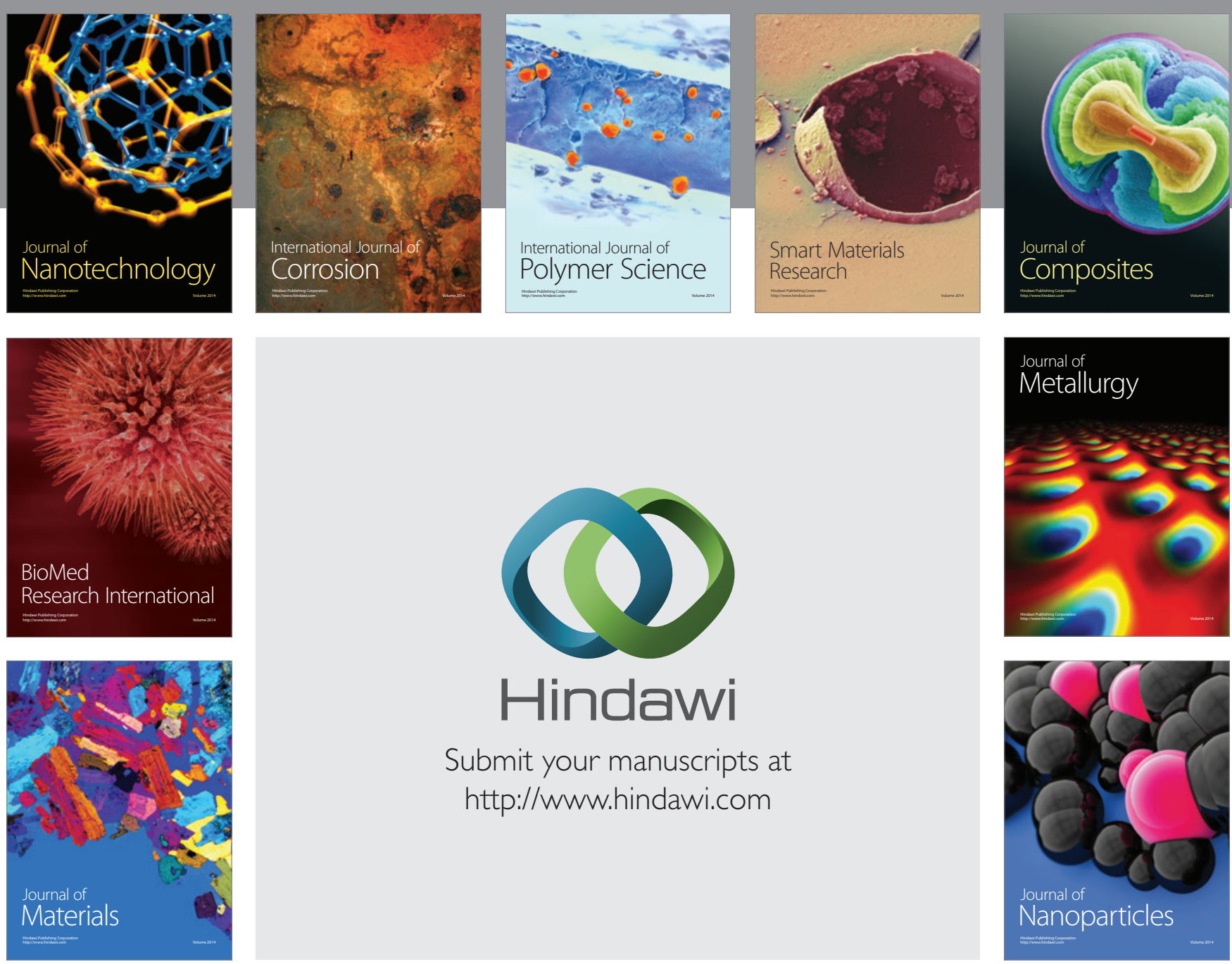

Submit your manuscripts at http://www.hindawi.com
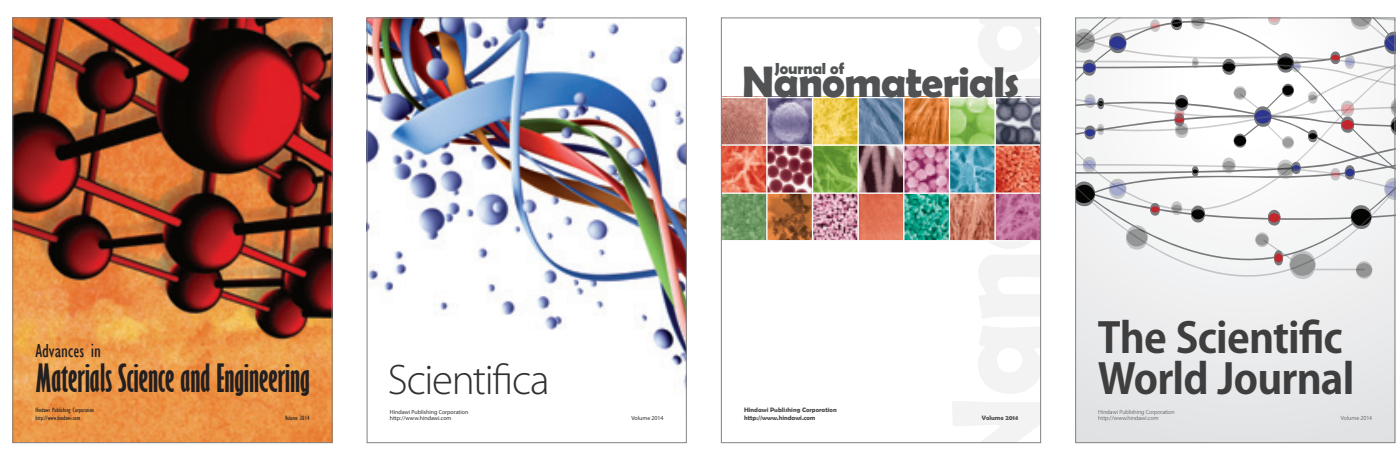

\section{The Scientific World Journal}
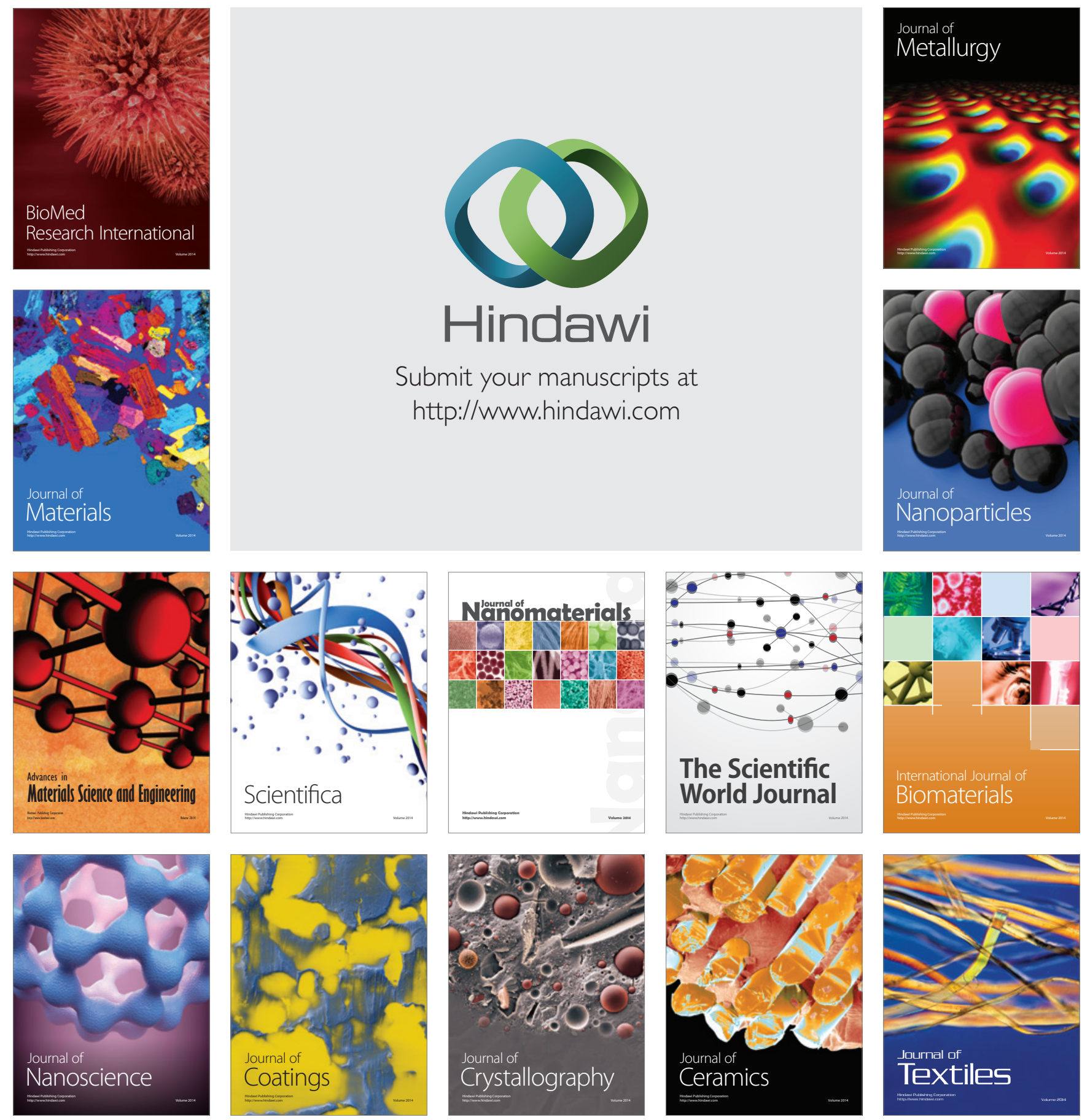